\title{
Periostin overexpression is associated with worse prognosis in nasopharyngeal carcinoma from endemic area: a cohort study
}

This article was published in the following Dove Press journal:

OncoTargets and Therapy

\author{
Yu-Ching Wei, ${ }^{1,2}$ Sheau-Fang \\ Yang, ${ }^{2,3}$ Shih-Lun Chang, ${ }^{4,5}$ \\ Tzu-Ju Chen, ${ }^{5,6}$ Sung-Wei \\ Lee, ${ }^{7}$ Hung-Sung Chen, \\ Li-Ching Lin, ${ }^{8}$ Chien-Feng \\ $\mathrm{Li}^{6,9,10}$
}

'Department of Pathology, Kaohsiung Municipal Ta-Tung Hospital, Kaohsiung, Taiwan; ${ }^{2}$ Department of Pathology, School of Medicine, College of Medicine, Kaohsiung Medical University, Kaohsiung, Taiwan; ${ }^{3}$ Department of Pathology, Kaohsiung Medical University Hospital, Kaohsiung, Taiwan; ${ }^{4}$ Department of Otolaryngology, Chi Mei Medical Center, Tainan, Taiwan; ${ }^{5}$ Department of Optometry, Chung Hwa University of Medical Technology, Tainan, Taiwan; ${ }^{6}$ Department of Pathology, Chi Mei Medical Center, Tainan, Taiwan; ${ }^{7}$ Department of Radiation Oncology, Chi Mei Medical Center, Liouying, Tainan, Taiwan; ${ }^{8}$ Department of Radiation Oncology, Chi Mei Medical Center, Tainan, Taiwan; ${ }^{~} \mathrm{National}$ Institute of Cancer Research, National Health Research Institute, Tainan, Taiwan; ${ }^{10}$ Department of Biotechnology, Southern Taiwan University of Science and Technology, Tainan, Taiwan

Correspondence: Chien-Feng Li Department of Pathology, Chi Mei Medical Center, No. 90I, Zhonghua Road, Yongkang Distrist, Tainan 710, Taiwan

Tel +886628 I 28I I ext 53680

$\mathrm{Fax}+886625 \mathrm{I} \mid 235$

Email angelo.p@yahoo.com.tw

\section{Li-Ching Lin}

Department of Radiation Oncology, Chi Mei Medical Center, No. 90I,

Zhonghua Road, Yongkang District, Tainan 710, Taiwan

Email yimei.liching@msa.hinet.net
Purpose: Nasopharyngeal carcinoma (NPC) is a heterogeneous disease. We searched for genes that function in cell adhesion in GSE12452, a published transcriptomic database. We found that POSTN, which encodes periostin (POSTN), was significantly upregulated in NPC tumorigenesis. Herein, we sought to analyze the expression of POSTN and its prognostic significances in patients with NPC.

Materials and methods: In this single-institution retrospective study, we determined and analyzed POSTN expression by immunohistochemistry and H-score method, respectively, in 124 patients with NPC. The results indicated that POSTN expression was correlated with the clinicopathologic features, disease-specific survival (DSS), distant metastasis-free survival (DMFS), and local recurrence-free survival (LRFS) of NPC. We performed univariate and multivariate analyses to determinate the statistical significance.

Results: High POSTN expression was significantly associated with lymph node metastasis ( $p=0.004)$ and advanced American Joint Committee on Cancer (AJCC) stage $(p=0.006)$. In univariate analysis, high POSTN expression served as a significant prognostic factor for worse DSS ( $p=0.0002)$, DMFS ( $p=0.0138)$, and LRFS ( $p=0.0028)$. In multivariate Cox regression analyses, which was adjusted for AJCC stages, POSTN expression was independently associated with cancer-related death (HR: 2.311; 95\% CI: $1.327-4.027 ; p=0.003$ ) and local tumor recurrence (HR: 3.187; 95\% CI: $1.108-4.408 ; p=0.024$ ).

Conclusion: High POSTN expression is associated with tumor aggressiveness and worse clinical outcomes in NPC, indicating that it may be a potential prognostic biomarker and a therapeutic target.

Keywords: nasopharyngeal cancer, periostin, oncologic, outcomes

\section{Introduction}

Nasopharyngeal carcinoma (NPC) is a cancer of the head and neck region arising from the nasopharynx epithelium. ${ }^{1,2}$ It has an extremely unique pattern of geographical distribution, and most new cases are in Eastern and Southeastern Asia. ${ }^{1-3}$ Current therapeutic decisions are based mainly on disease stage..$^{1,4,5}$ The contemporary consensus is to treat early-stage disease with radiotherapy alone, and advanced stage disease with radiotherapy and concurrent chemotherapy. ${ }^{1,4,5}$

Although localized disease can be effectively controlled with radiotherapy alone, distant metastasis is a critical challenge, and the treatment outcome of metastatic NPC remains disappointing. . $^{1,45}$ Many clinicopathologic variables have been reported to predict treatment outcome. Among these, TNM staging is still the most important prognostic factors in NPC. ${ }^{1,4,5}$ However, patients with the same clinical stage often 
undergo substantially different clinical courses and outcomes. Thus, new biomarkers for more precise prognostic prediction in NPC should be explored.

During disease progression or metastasis, cancer cells migrate through the extracellular matrix (ECM) for intravasation into the blood and lymphatic vessels. ${ }^{6}$ Many cell adhesion molecules participate in this process. ${ }^{6}$ Through data mining on a published transcriptome of NPC in the Gene Expression Omnibus dataset (GEO, NCBI, Bethesda, MD, USA) with a focus on cell adhesion (GO:0007155), we identified FN1 (encoding fibronectin 1) and POSTN (encoding periostin) as the two most significantly upregulated genes in NPC tumorigenesis. We found that FN1 was the most significantly upregulated gene involving cell migration in NPCs. ${ }^{7}$ High FN1 expression was significantly associated with worse clinical outcomes. ${ }^{7}$ POSTN, also known as osteoblast-specific factor 2, is a component of the ECM involved in regulating intercellular adhesion. ${ }^{8}$ Recent studies have shown that POSTN is involved in tumorigenesis and tumor progression of various tumors, such as breast, lung, prostate and ovarian cancer. ${ }^{8-11}$ In prostate cancer, POSTN overexpression was associated with poorly differentiated tumors and advanced cancer stage and was correlated with clinical outcome, including PSA recurrence-free survival and overall survival. ${ }^{8}$ Therefore, we further investigated the association between POSTN expression and prognosis in NPC (Figure 1).

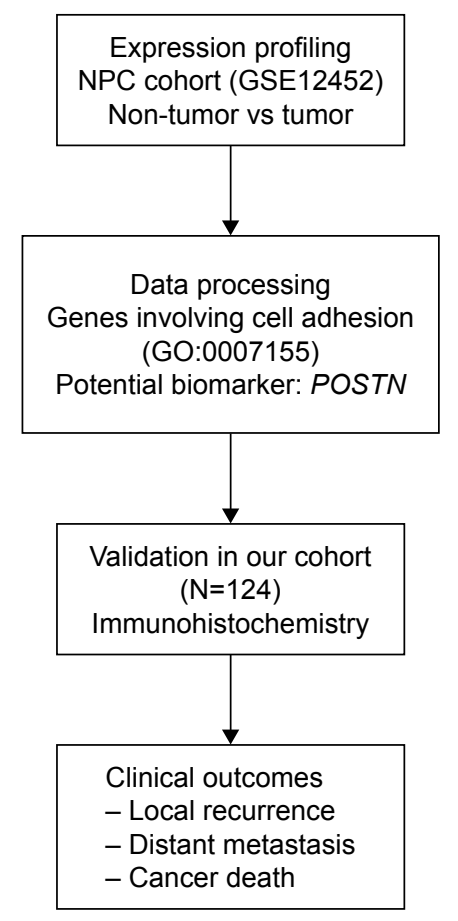

Figure I Flow chart of research.

Abbreviations: NPC, nasopharyngeal carcinoma; POSTN, periostin.

\section{Materials and methods}

\section{Analysis of expression profile}

Through data mining of the Gene Expression Omnibus database (National Center for Biotechnology Information, Bethesda, MD, USA), we identified one dataset, GSE12452, obtained using the Affymetrix Human Genome U133 Plus 2.0 Array platform by analysis of 31 NPC tissues, and 10 normal nasopharyngeal tissues. We imported the raw files and computed the gene expression levels identified by probe sets, without preselection or filtering, using Nexus Expression 3 software (BioDiscovery, EI Segundo, CA, USA). Supervised comparative analysis and functional profiling were performed to identify statistically significant differentially expressed genes, with special attention to genes with molecular function involving cell adhesion (GO:0007155). Only genes showing significantly different expression $(\log 2$ ratio $>3, p<0.01$ ) were selected.

\section{Patients and tumor samples}

On the basis of the Declaration of Helsinki and local ethic regulations, the institutional review board (IRB) of Chi Mei Medical Center approved this study (IRB10302013). In this study, the IRB of Chi Mei Medical Center granted the research use of formalin-fixed materials from BioBank of Chi Mei Medical Center and waived the need of informed consents from participants due to anonymous processing for research purpose that excluded the identification of personal information of participants. Available paraffin-embedded tissue blocks were retrieved from 124 patients with NPC diagnosed between January 1993 and December 2002. These patients showed no signs of distant metastasis at first presentation and underwent biopsy at initial diagnosis. Two pathologists reappraised the histological subtypes according to the current World Health Organization (WHO) classification. The tumor staging was reevaluated using the 7th American Joint Committee on Cancer (AJCC) system. ${ }^{12}$

\section{Immunohistochemistry}

Tissue sections were cut from paraffin-embedded blocks at $3 \mu \mathrm{m}$ thickness as described previously. ${ }^{13,14}$ Slides were processed followed by deparaffinization, rehydration, antigen retrieval, and blockage of endogenous peroxidase. Subsequently, the sections were incubated with the primary antibody against POSTN (1:100; Lifespan BioScience, Seattle, WA, USA, Cat No LS-B3986) for 1 hour. We detected the primary antibody based on the ChemMate DAKO EnVision Detection Kit (K5001, Carpinteria, CA, USA). To ensure the quality of immunostaining, tissues sections incubated without the primary antibody were used as negative controls. 
Two pathologists who were blinded to the study scored the intensity and distribution of positive immunostaining tumor cells using a multiheaded microscope to reach a consensus on the $\mathrm{H}$-score, using the following equation: $\Sigma \operatorname{Pi}(i+1)$, where $i$ is the intensity of stained tumor cells ( 0 to $3+$ ), and $\mathrm{Pi}$ is the percentage of stained tumor cells, varying from $0 \%$ to $100 \% .{ }^{15}$ The immunoreactivity of POSTN was dichotomized into high and low expression according to the median H-score of 205.

\section{Treatment and follow-up}

All patients received a complete course of radiotherapy with the daily fractioned dose of 180-200 cGy at five fractions weekly, to achieve a total dose of $\geqq 7,000$ cGy. Those with stage II-IV disease also received cisplatin-based chemotherapy following published protocols. ${ }^{16}$ Patient response was classified according to the previously reported WHO criteria. ${ }^{17}$ In total, this study included 110 complete and 7 partial responders.

\section{Cell culture}

Dysplastic keratinocyte (DOK), NPC-derived HONE1 and TW01 cell lines were obtained from European Collection of Animal Cell Cultures (ECACC), American Type Culture Collection (ATCC), and Food Industry Research and Development Institute, Taiwan, respectively. The culture conditions of DOK, HONE1, and TW01 cell lines were previously described. ${ }^{18}$ Briefly, all cells were maintained in Dulbecco's Modified Eagle's Medium (DMEM), supplemented with $10 \%$ fetal bovine serum, $100 \mu \mathrm{g} / \mathrm{mL}$ streptomycin, and 100 units $/ \mathrm{mL}$ penicillin at a $37^{\circ} \mathrm{C}, 5 \%$ $\mathrm{CO}_{2}$ humidified incubator.

\section{Western blot analysis}

Equal amounts of total protein $(25 \mu \mathrm{g})$ extracted from the cell lines were separated on $10 \%$ sodium dodecylsulfate polyacrylamide gel electrophoresis gel NuPAGE (Invitrogen), and transferred to polyvinylidene difluoride membranes (Amersham Biosciences, Bucks, UK). After blocking, the membranes were probed with the primary antibodies against POSTN (1:50; Lifespan BioScience, Cat No LS-B3986). Glyceraldehyde 3-phosphate dehydrogenase was used as the loading control (Clone 6C5, 1:10,000; Millipore, Beverly, MA, USA). After incubation with the secondary antibody, the protein expression was visualized using the enhanced chemiluminescence system (Amersham Biosciences).

\section{Statistical analyses}

All statistical analyses were performed using SPSS ${ }^{\circledR}$ V.17.0. The associations of POSTN expression with various clinicopathologic features were evaluated by Pearson's chi-square test. We analyzed three end points, including disease-specific survival (DSS), distant metastasis-free survival (DMFS), and local recurrence-free survival (LRFS). DSS, DMFS, and LRFS were calculated from the starting date of radiotherapy to the date of development of an event. Univariate survival analyses were performed using KaplanMeier plots, and survival was evaluated by the log-rank test. In the multivariate Cox proportional hazards regression model, all significant parameters at the univariate level were entered to compare their independent prognostic effects. For all analyses, we used two-sided tests of significance with $p<0.05$ being considered significant.

\section{Results POSTN transcript is significantly upregulated in NPC}

From the public transcriptomic dataset of 31 NPC cases, we focused on the genes involved in the regulation of cell adhesion. We found that only six probes covering three genes showed significant overexpression during NPC development. FN1 and POSTN were the most significantly upregulated genes in NPC. Our previous study has shown that $F N 1$ was the most significantly upregulated gene involved in cell migration in NPC. ${ }^{7}$ We selected POSTN for further validation due to the significant statistical power $(p<0.0001)$ and the prominent $\log 2$-transformed expression level (log2 ratio: 3.38; Figure 2 and Table 1).

\section{Association between POSTN expression and clinicopathologic features of NPC}

Of 124 patients with NPC, 95 (76.6\%) were men and 29 $(23.4 \%)$ were women, and their mean age was 48.6 years (range, 20-83). A total of 114 patients were monitored regularly after radiotherapy, with 3-141 months of follow-up (mean, 67.0 months). According to the AJCC stage, 7 (5.6\%), $31(25.0 \%), 46(37.1 \%)$, and $40(32.3 \%)$ cases were classified as stage I, II, III, and IV, respectively. With regard to histological subtypes, 5 (4.0\%) patients had keratinizing squamous cell carcinomas, 54 (43.5\%) had non-keratinizing differentiated carcinomas, and 65 (52.4\%) patients had nonkeratinizing, undifferentiated carcinomas.

During follow-up, 59 (47.6\%) patients died of the disease, $49(39.5 \%)$ developed distant tumor metastasis, and $37(29.8 \%)$ patients had local tumor recurrence. Whether with squamous metaplasia or not, POSTN immunoexpression was rarely found in cases of non-neoplastic nasopharyngeal mucosal epithelia (Figure 3A and B). However, positive 


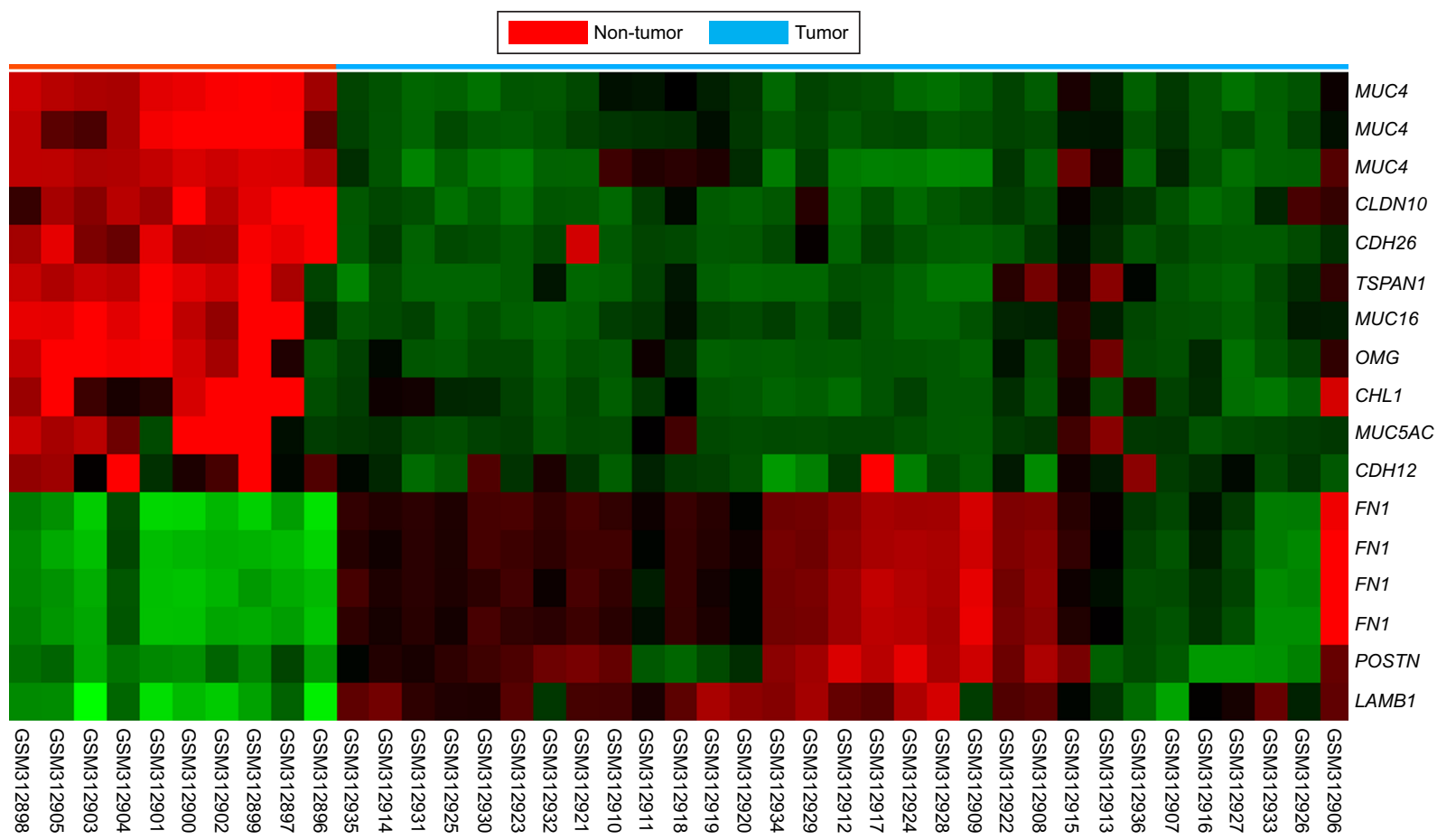

Figure 2 By reappraising the published transcriptomic datasets of NPC vs non-neoplastic nasopharyngeal tissues samples (GSEI2452), with special attention to those associated with cell adhesion (GO:0007I55),

Notes: POSTN was found to be one of the most significantly upregulated genes.

Abbreviations: NPC, nasopharyngeal carcinoma; POSTN, periostin.

staining was identified in some tumor tissues (Figure 3C and D). High POSTN expression was significantly associated with lymph node metastasis $(p=0.004)$ and advanced AJCC stage ( $p=0.006$; Table 2 ).

\section{Prognostic significance of POSTN expression}

Univariate and multivariate analyses were performed to evaluate the prognostic significances of POSTN expression. Univariate analysis revealed that primary tumor stage, lymph node status, AJCC stage, and POSTN expression were significantly associated with DSS, DMFS, and LRFS (Table 3). In multivariate Cox regression analysis, POSTN expression and AJCC stage remained independently associated with DSS (HR: $2.311 ; 95 \%$ CI: $1.327-4.027 ; p=0.003$ ) and LRFS (HR: 3.187; 95\% CI: $1.108-4.408 ; p=0.024)$ together with AJCC stage (Table 4). Kaplan-Meier analysis also showed that high POSTN expression also predicted significantly worse DSS ( $p=0.0002$, Figure 4A), DMFS ( $p=0.0138$, Figure 4B), and LRFS ( $p=0.0028$, Figure 4C).

We also evaluated POSTN endogenous protein expression in a non-tumor, premalignant keratinocyte (DOK) and two NPC cells. Of note, POSTN was significant higher expression in both HONE1 and TW01 cells than in DOK (Figure 5), implicating its potential tumorigenic role in NPC.

\section{Discussion}

NPC is characterized as a clinically heterogeneous malignancy. Patients with the same cancer staging present different risks of local tumor recurrence, distant metastasis, and cancer mortality. ${ }^{1-5}$ In Taiwan, NPC is the second most common cancer in incidence and mortality among head and neck cancers. Therefore, identifying molecular markers for early prediction of cancer progression may help physicians stratify patients according to varying risks and to decide the treatment program. In this study, high POSTN expression was significantly associated with tumor aggressiveness. Furthermore, we demonstrated the association of POSTN expression with LRFS and DSS after adjusting AJCC stage in patients with NPC. The risk of cancer-related death and distant metastasis was increased two fold and that of local tumor recurrence increased by three fold in patients with NPC with high POSTN expression. These findings indicate that POSTN status can also be a clinicopathologic predictor to improve risk stratification for NPC patients.

Human POSTN is encoded by a gene located on chromosome 13 (13q13.3). ${ }^{19}$ POSTN has been found in various normal tissues and organs, including the lungs, testis, thyroid, stomach, vagina, ovary, colon, prostate, and breast. ${ }^{20,21}$ The encoded glycoprotein plays important roles in the physiological process of epithelial-mesenchymal transition(EMT), 
Table I Summary of differentially expressed genes associated with cell adhesion identified in the transcriptome of nasopharyngeal carcinoma

\begin{tabular}{|c|c|c|c|c|c|c|}
\hline Probe & $\begin{array}{l}\text { Comparison } \\
\text { log ratio }\end{array}$ & $\begin{array}{l}\text { Comparison } \\
\text { p-value }\end{array}$ & $\begin{array}{l}\text { Gene } \\
\text { symbol }\end{array}$ & Gene name & Biological process & Molecular function \\
\hline 217109_at & $-5.995 \mathrm{I}$ & $<0.00001$ & MUC4 & $\begin{array}{l}\text { Mucin 4; cell surface } \\
\text { associated }\end{array}$ & Cell adhesion, cell-matrix adhesion & $\begin{array}{l}\text { ErbB-2 class receptor binding, } \\
\text { extracellular matrix structural } \\
\text { constituent, protein binding }\end{array}$ \\
\hline 217110_s_at & -5.4909 & $<0.0000$ I & MUC4 & $\begin{array}{l}\text { Mucin 4; cell surface } \\
\text { associated }\end{array}$ & $\begin{array}{l}\text { Cell adhesion, cell-matrix adhesion, } \\
\text { transport }\end{array}$ & $\begin{array}{l}\text { ErbB-2 class receptor binding, } \\
\text { extracellular matrix structural } \\
\text { constituent, protein binding, } \\
\text { transporter activity }\end{array}$ \\
\hline 238720_at & -5.1279 & $<0.00001$ & OMG & $\begin{array}{l}\text { Oligodendrocyte } \\
\text { myelin glycoprotein }\end{array}$ & Cell adhesion & $\begin{array}{l}\text { GPI anchor binding, protein } \\
\text { binding }\end{array}$ \\
\hline 209114_at & -4.9189 & $<0.0000 \mathrm{I}$ & TSPANI & Tetraspanin I & $\begin{array}{l}\text { Cell adhesion, cell motility, cell } \\
\text { proliferation }\end{array}$ & $\begin{array}{l}\text { Protein binding, thiamine } \\
\text { uptake transmembrane } \\
\text { transporter activity }\end{array}$ \\
\hline 211719_x_at & 4.3873 & $<0.00001$ & FNI & Fibronectin I & $\begin{array}{l}\text { Acute-phase response, cell } \\
\text { adhesion, cell migration, response } \\
\text { to wounding, transmembrane } \\
\text { receptor protein tyrosine kinase } \\
\text { signaling pathway }\end{array}$ & $\begin{array}{l}\text { Collagen binding, } \\
\text { extracellular matrix structural } \\
\text { constituent, heparin binding, } \\
\text { protein binding }\end{array}$ \\
\hline 204895_x_at & -4.2689 & $<0.0000$ I & MUC4 & $\begin{array}{l}\text { Mucin } 4 \text {; cell surface } \\
\text { associated }\end{array}$ & $\begin{array}{l}\text { Cell adhesion, cell-matrix adhesion, } \\
\text { transport }\end{array}$ & $\begin{array}{l}\text { ErbB-2 class receptor binding, } \\
\text { extracellular matrix structural } \\
\text { constituent, protein binding, } \\
\text { transporter activity }\end{array}$ \\
\hline 220196_at & -4.0657 & $<0.00001$ & MUCI6 & $\begin{array}{l}\text { Mucin 16; cell } \\
\text { surface associated }\end{array}$ & Cell adhesion & Protein binding \\
\hline 212464_s_at & 4.0197 & $<0.0000$ I & FNI & Fibronectin I & $\begin{array}{l}\text { Acute-phase response, cell } \\
\text { adhesion, cell migration, response } \\
\text { to wounding, transmembrane } \\
\text { receptor protein tyrosine kinase } \\
\text { signaling pathway }\end{array}$ & $\begin{array}{l}\text { Collagen binding, } \\
\text { extracellular matrix structural } \\
\text { constituent, heparin binding, } \\
\text { protein binding }\end{array}$ \\
\hline 210495_x_at & 3.6034 & $<0.00001$ & FNI & Fibronectin I & $\begin{array}{l}\text { Acute-phase response, cell adhesion, } \\
\text { cell migration, response to wounding, } \\
\text { transmembrane receptor protein } \\
\text { tyrosine kinase signaling pathway }\end{array}$ & $\begin{array}{l}\text { Collagen binding, } \\
\text { extracellular matrix structural } \\
\text { constituent, heparin binding, } \\
\text { protein binding }\end{array}$ \\
\hline 216442_x_at & 3.5853 & $<0.00001$ & FNI & Fibronectin I & $\begin{array}{l}\text { Acute-phase response, cell } \\
\text { adhesion, cell migration, response } \\
\text { to wounding, transmembrane } \\
\text { receptor protein tyrosine kinase } \\
\text { signaling pathway }\end{array}$ & $\begin{array}{l}\text { Collagen binding, } \\
\text { extracellular matrix structural } \\
\text { constituent, heparin binding, } \\
\text { protein binding }\end{array}$ \\
\hline 205328_at & -3.5736 & $<0.00001$ & CLDNIO & Claudin 10 & $\begin{array}{l}\text { Calcium-independent cell-cell } \\
\text { adhesion, cell adhesion }\end{array}$ & $\begin{array}{l}\text { Identical protein binding, } \\
\text { protein binding, structural } \\
\text { molecule activity }\end{array}$ \\
\hline 214385_s_at & -3.5388 & $<0.00001$ & MUC5AC & $\begin{array}{l}\text { Mucin } 5 A C ; \\
\text { oligomeric mucus/ } \\
\text { gel-forming }\end{array}$ & $\begin{array}{l}\text { Cell adhesion, digestion, fibril } \\
\text { organization and biogenesis }\end{array}$ & $\begin{array}{l}\text { Extracellular matrix } \\
\text { constituent; lubricant activity, } \\
\text { extracellular matrix structural } \\
\text { constituent, protein binding }\end{array}$ \\
\hline 232306_at & -3.4379 & $<0.00001$ & $\mathrm{CDH} 26$ & Cadherin-like 26 & $\begin{array}{l}\text { Cell adhesion, homophilic cell } \\
\text { adhesion }\end{array}$ & $\begin{array}{l}\text { Calcium ion binding, protein } \\
\text { binding }\end{array}$ \\
\hline 210809_s_at & 3.3769 & $<0.00001$ & POSTN & $\begin{array}{l}\text { Periostin; osteoblast } \\
\text { specific factor }\end{array}$ & Cell adhesion, skeletal development & $\begin{array}{l}\text { Heparin binding, protein } \\
\text { binding }\end{array}$ \\
\hline 20I505_at & 3.0358 & $<0.00001$ & $\angle A M B I$ & Laminin; beta I & $\begin{array}{l}\text { Cell adhesion, neurite development, } \\
\text { odontogenesis, positive regulation } \\
\text { of cell migration, positive regulation } \\
\text { of epithelial cell proliferation }\end{array}$ & $\begin{array}{l}\text { Extracellular matrix } \\
\text { structural constituent, } \\
\text { protein binding, structural } \\
\text { molecule activity }\end{array}$ \\
\hline 20459I_at & -3.0226 & $<0.00001$ & CHLI & $\begin{array}{l}\text { Cell adhesion } \\
\text { molecule with } \\
\text { homology to } \\
\text { LICAM (close } \\
\text { homolog of LI) }\end{array}$ & $\begin{array}{l}\text { Axon guidance, behavior, cell } \\
\text { adhesion, cell differentiation, } \\
\text { multicellular organismal } \\
\text { development, nervous system } \\
\text { development, neurite development, } \\
\text { neuron migration, signal transduction }\end{array}$ & Protein binding \\
\hline
\end{tabular}

Abbreviation: POSTN, periostin. 

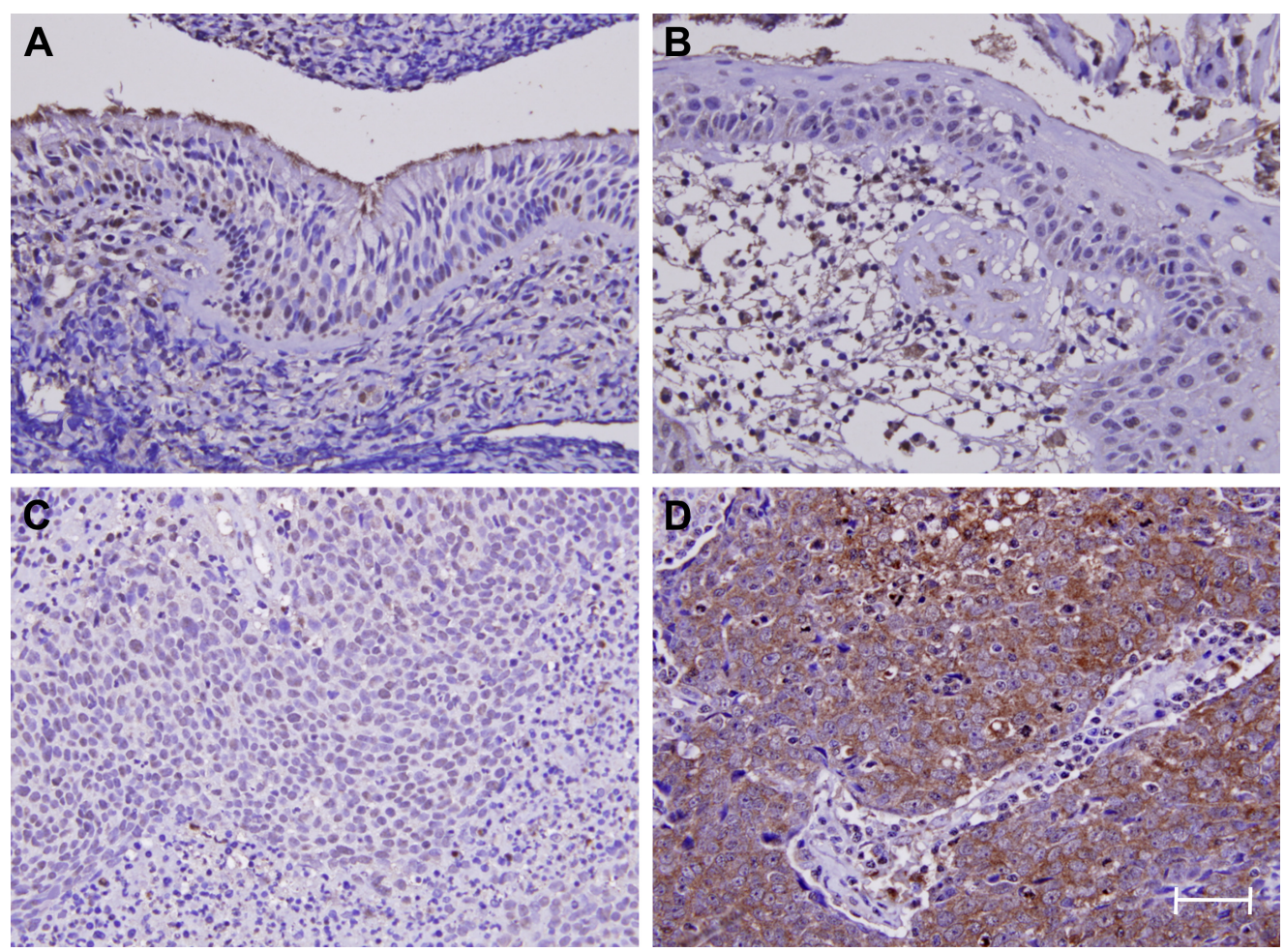

Figure 3 Periostin immunoexpression.

Notes: In normal nasopharyngeal mucosa (A) and that with (B) squamous metaplasia, periostin staining is barely detected. Representative low-stage NPC (C) shows weak periostin staining; whereas the high-stage lesion (D) exhibits diffuse and strong staining. Scale bar $=100 \mu \mathrm{m}$; magnification $\times 400$.

Abbreviation: NPC, nasopharyngeal carcinoma.

which is necessary for proper embryogenesis. ${ }^{20,21}$ POSTN is also an ECM protein involved in regulating intercellular adhesion through interactions with other ECM proteins, such as fibronectin, tenascin-C, and collagen $\mathrm{V} .{ }^{8,22,23}$ The ECM protein POSTN was found to be a marker and an inducer of EMT, a process that is characterized by the dissemination of

Table 2 Associations of periostin expression with other important clinicopathologic variables

\begin{tabular}{|c|c|c|c|c|}
\hline \multirow[t]{2}{*}{ Parameters } & \multirow[t]{2}{*}{ Category } & \multicolumn{2}{|c|}{$\begin{array}{l}\text { Periostin } \\
\text { expression, } n\end{array}$} & \multirow[t]{2}{*}{$p$-value } \\
\hline & & Low & $\overline{\text { High }}$ & \\
\hline \multirow[t]{2}{*}{ Gender } & Male & 43 & 52 & 0.056 \\
\hline & Female & 19 & 10 & \\
\hline \multirow[t]{2}{*}{ Age (years) } & $<60$ & 51 & 47 & 0.378 \\
\hline & $\geq 60$ & 11 & 15 & \\
\hline \multirow[t]{2}{*}{ Primary tumor $(\mathrm{T})$} & $\mathrm{TI}-\mathrm{T} 2$ & 42 & 38 & 0.453 \\
\hline & T3-T4 & 20 & 24 & \\
\hline \multirow[t]{2}{*}{ Nodal status (N) } & No-NI & 36 & 20 & $0.004 *$ \\
\hline & N2-N3 & 26 & 42 & \\
\hline \multirow[t]{2}{*}{ Stage } & I-II & 26 & 12 & $0.006 *$ \\
\hline & III-IV & 36 & 50 & \\
\hline \multirow[t]{3}{*}{ Histological grade } & Keratinized & 3 & 2 & 0.814 \\
\hline & Non-keratinized & 28 & 26 & \\
\hline & Undifferentiated & 31 & 34 & \\
\hline
\end{tabular}

Note: *Statistically significant. primary tumor epithelial cells to the sites of metastasis and the dedifferentiation program that leads to cancer progression. ${ }^{24,25}$

Increased POSTN expression has been found in many malignancies, including breast, lung, colorectal, stomach, pancreatic, prostate, and ovarian cancer. ${ }^{8-11}$ POSTN mRNA and protein expression are higher in breast cancer tissue than in normal breast tissue. POSTN expression was significantly associated with tumor size, and expression of progesterone and estrogen receptor, vascular endothelial growth factor R1, R2, and A. ${ }^{26}$ Moreover, POSTN has been shown to promote cell survival and induce tumor angiogenesis in breast cancer. ${ }^{24,27}$ In lung cancer, some researchers demonstrated significant association between POSTN expression and tumor size, disease stage, lymph node metastasis, and lymphatic invasion..$^{28}$ High POSTN expression is also significantly related to cancer progression and worse patients' outcomes. ${ }^{28}$ In head and neck squamous cell carcinoma, Kudo et al demonstrated that POSTN overexpression promoted tumor invasion, anchorage-independent growth, metastasis, and lymph angiogenesis. ${ }^{29,30}$

Although the exact roles and signaling pathways involving POSTN in NPC tumorigenesis and cancer metastasis are still unclear, POSTN expression may be an indicator of a 
Table 3 Univariate log-rank analyses

\begin{tabular}{|c|c|c|c|c|c|c|c|c|}
\hline \multirow[t]{2}{*}{ Parameters } & \multirow[t]{2}{*}{ Category } & \multirow{2}{*}{$\begin{array}{l}\text { No of } \\
\text { cases }\end{array}$} & \multicolumn{2}{|l|}{ DSS } & \multicolumn{2}{|l|}{ DMFS } & \multicolumn{2}{|l|}{ LRFS } \\
\hline & & & $\begin{array}{l}\text { No of } \\
\text { events }\end{array}$ & $p$-value & $\begin{array}{l}\text { No of } \\
\text { events }\end{array}$ & $p$-value & $\begin{array}{l}\text { No of } \\
\text { events }\end{array}$ & $p$-value \\
\hline \multirow[t]{2}{*}{ Gender } & Male & 95 & 45 & 0.7870 & 38 & 0.6128 & 30 & 0.3240 \\
\hline & Female & 29 & 14 & & II & & 7 & \\
\hline \multirow[t]{2}{*}{ Age (years) } & $<60$ & 98 & 48 & 0.8600 & 42 & 0.3091 & 29 & 0.8206 \\
\hline & $\geq 60$ & 26 & 11 & & 7 & & 8 & \\
\hline \multirow[t]{2}{*}{ Primary tumor $(\mathrm{T})$} & $\mathrm{TI}-\mathrm{T} 2$ & 80 & 32 & $0.0289 *$ & 25 & $0.0085^{*}$ & 19 & $0.0180^{*}$ \\
\hline & T3-T4 & 44 & 27 & & 24 & & 18 & \\
\hline \multirow[t]{2}{*}{ Nodal status $(\mathrm{N})$} & No-NI & 56 & 18 & $0.0008^{*}$ & 17 & $0.0132 *$ & 12 & $0.0160 *$ \\
\hline & N2-N3 & 68 & 41 & & 32 & & 25 & \\
\hline \multirow[t]{2}{*}{ Stage } & I-II & 38 & 10 & $0.0020^{*}$ & 9 & $0.0072 *$ & 5 & $0.0026^{*}$ \\
\hline & III-IV & 86 & 49 & & 40 & & 32 & \\
\hline \multirow[t]{2}{*}{ Histological grade } & Keratinized/non-keratinized & 47 & 20 & 0.1980 & 17 & 0.2753 & 15 & 0.9521 \\
\hline & Undifferentiated & 77 & 39 & & 32 & & 22 & \\
\hline \multirow[t]{2}{*}{ Periostin } & Low expression $(\mathrm{H}$-score $<$ median $)$ & 62 & 20 & $0.0002 *$ & 20 & $0.0138 *$ & 13 & $0.0028^{*}$ \\
\hline & High expression ( $\mathrm{H}$-score $\geq$ median) & 62 & 39 & & 29 & & 24 & \\
\hline
\end{tabular}

Note: *Statistically significant.

Abbreviations: DMFS, distal metastasis-free survival; DSS, disease-specific survival; LRFS, local recurrence-free survival.

Table 4 Multivariate survival analyses

\begin{tabular}{|c|c|c|c|c|c|c|c|c|c|c|}
\hline \multirow[t]{2}{*}{ Parameter } & \multirow[t]{2}{*}{ Category } & \multicolumn{3}{|l|}{ DSS } & \multicolumn{3}{|c|}{ DMFS } & \multicolumn{3}{|l|}{ LRFS } \\
\hline & & HR & $95 \% \mathrm{Cl}$ & $p$-value & HR & $95 \% \mathrm{Cl}$ & $p$-value & HR & $95 \% \mathrm{Cl}$ & $p$-value \\
\hline \multirow[t]{2}{*}{ Stage } & I-II & 1 & & & 1 & & & 1 & & \\
\hline & III-IV & 2.235 & $1.113-4.488$ & $0.024^{*}$ & 2.275 & $1.086-4.767$ & $0.029 *$ & 2.210 & $1.222-8.316$ & $0.018^{*}$ \\
\hline \multirow[t]{2}{*}{ Periostin exp. } & Low exp. & 1 & & & 1 & & & 1 & & \\
\hline & High exp. & 2.311 & $1.327-4.027$ & $0.003^{*}$ & 1.727 & $0.962-3.100$ & 0.067 & 3.187 & I.108-4.408 & $0.024 *$ \\
\hline
\end{tabular}

Note: *Statistically significant.

Abbreviations: DSS, disease-specific survival; DMFS, distal metastasis-free Survival.
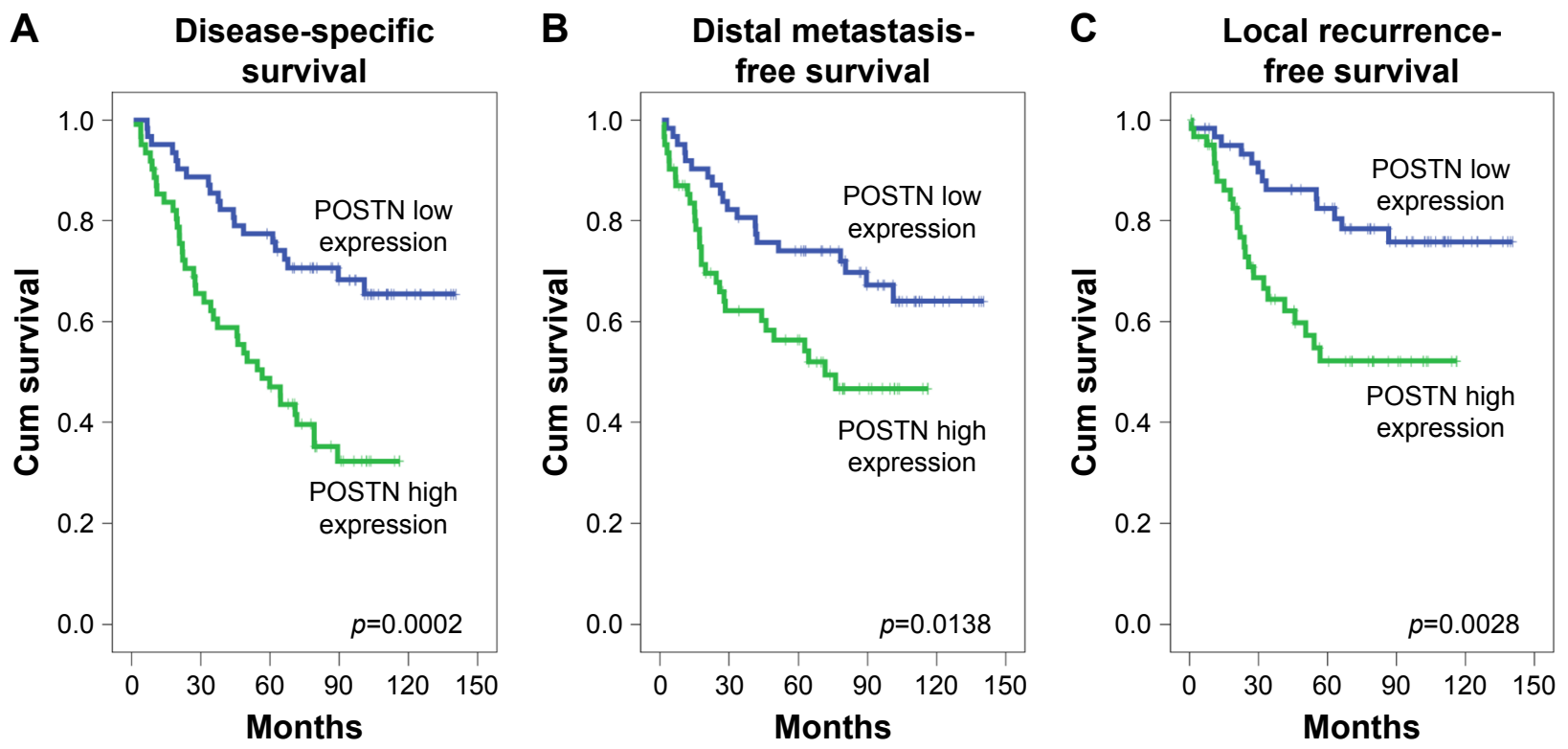

Figure 4 Kaplan-Meier survival curves in the NPC patients according to POSTN immunoexpression.

Note: POSTN immunohistochemical overexpression is a strong prognosticator of worse disease-specific survival (A), distant metastasis-free survival (B), and local recurrence-free survival $(\mathbf{C})$.

Abbreviations: NPC, nasopharyngeal carcinoma; POSTN, periostin. 


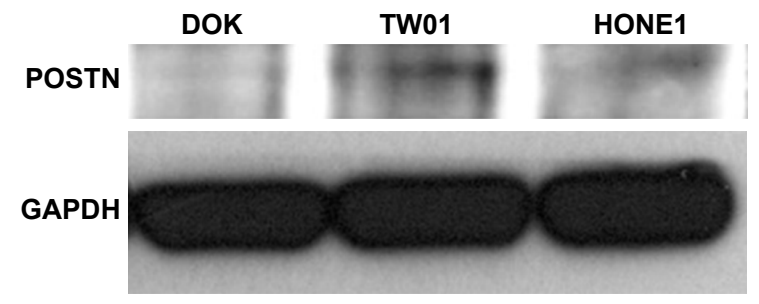

Figure 5 Western blot of endogenous POSTN expression in NPC cells. Notes: POSTN was significantly higher expressed in both HONEI and TWOI NPC cells than in non-tumor DOK cell.

Abbreviations: DOK, dysplastic keratinocyte; NPC, nasopharyngeal carcinoma; POSTN, periostin.

special subtype of NPC with aggressive pathologic features and worse prognosis. In breast and lung cancers, POSTN binds to integrins and activates Akt/PKB- and FAK-mediated signaling pathways, enhancing tumor invasion, metastasis, and angiogenesis. ${ }^{31}$ Interestingly, a POSTN-targeting positron emission tomography probe has been developed and applied in the preclinical setting for noninvasive assessment of the tumor microenvironment in esophageal cancer. ${ }^{32}$ However, further studies are needed to elucidate the significant molecular pathways involving POSTN in NPC.

There are several limitations to this study. First, this is a retrospective single-center study. Second, we could not elucidate the exact molecular mechanism causing adverse outcome in POSTN-overexpressing NPC. Third, variations exist in immunohistochemistry by using different scoring system. In this study, we evaluated both the percentage and intensity of positively stained tumor cells to generate an $\mathrm{H}$-score because of its excellent correlation to Western blot assay. ${ }^{33}$ Besides, all slides were scored by two independent pathologists to minimize divergence and to reach a consensus for each case. Finally, prospective multi-institutional studies with a larger cohort are warranted to certify our observations.

\section{Conclusion}

We performed data mining and evaluated the prognostic significance of POSTN immunoexpression in a wellcharacterized series of patients with NPC. We found that POSTN expression is independently associated with cancerspecific mortality and tumor recurrence in patients with NPC. Our findings reinforce the potential role of POSTN in contributing to the aggressive behavior of NPC and may help risk-stratify patients. Moreover, our results justify the potential of anti-POSTN targeted therapy for NPC patients in the future.

\section{Acknowledgments}

This study was supported by Kaohsiung Municipal Ta-Tung Hospital (kmtth-105-007 and kmtth-106-010). The authors thank the BioBank and the Translational Research Laboratory of Human Cancers of Chi Mei Medical Center for technical supports.

\section{Disclosure}

The authors report no conflicts of interest in this work.

\section{References}

1. Chua MLK, Wee JTS, Hui EP, Chan ATC. Nasopharyngeal carcinoma. Lancet. 2016;387(10022):1012-1024.

2. Lo KW, To KF, Huang DP. Focus on nasopharyngeal carcinoma. Cancer Cell. 2004;5(5):423-428.

3. Sun X, Tong LP, Wang YT, et al. Can global variation of nasopharynx cancer be retrieved from the combined analyses of IARC Cancer Information (CIN) databases? PLoS One. 2011;6(7):e22039.

4. Chan AT, Gregoire V, Lefebvre JL, et al. Nasopharyngeal cancer: EHNS-ESMO-ESTRO Clinical Practice Guidelines for diagnosis, treatment and follow-up. Ann Oncol. 2012;23(Suppl 7):vii83-vii85.

5. Lee AW, Ma BB, Ng WT, Chan AT. Management of nasopharyngeal carcinoma: current practice and future perspective. J Clin Oncol. 2015; 33(29):3356-3364

6. Okegawa T, Pong RC, Li Y, Hsieh JT. The role of cell adhesion molecule in cancer progression and its application in cancer therapy. Acta Biochim Pol. 2004;51(2):445-457.

7. Ma LJ, Lee SW, Lin LC, et al. Fibronectin overexpression is associated with latent membrane protein 1 expression and has independent prognostic value for nasopharyngeal carcinoma. Tumour Biol. 2014; 35(2):1703-1712.

8. Ruan K, Bao S, Ouyang G. The multifaceted role of periostin in tumorigenesis. Cell Mol Life Sci. 2009;66(14):2219-2230.

9. Xu D, Xu H, Ren Y, et al. Cancer stem cell-related gene periostin: a novel prognostic marker for breast cancer. PLoS One. 2012;7(10):e46670.

10. Morra L, Rechsteiner M, Casagrande S, et al. Characterization of periostin isoform pattern in non-small cell lung cancer. Lung Cancer. 2012; 76(2):183-190.

11. Zhu M, Fejzo MS, Anderson L, et al. Periostin promotes ovarian cancer angiogenesis and metastasis. Gynecol Oncol. 2010;119(2):337-344.

12. Edge SB, Byrd DR, Compton CC, Fritz AG, Greene FL, Trotti A. AJCC Cancer Staging Manual. 7th ed. Heidelberg: Springer; 2010.

13. Lee YY, Chao TB, Sheu MJ, et al. Glutamate decarboxylase 1 overexpression as a poor prognostic factor in patients with nasopharyngeal carcinoma. J Cancer. 2016;7(12):1716-1723.

14. Wu YT, Yen SL, Li CF, et al. Overexpression of transient receptor protein cation channel subfamily a member 1 , confers an independent prognostic indicator in nasopharyngeal carcinoma. J Cancer. 2016;7(10): 1181-1188.

15. McCarty KS Jr, Szabo E, Flowers JL, et al. Use of a monoclonal antiestrogen receptor antibody in the immunohistochemical evaluation of human tumors. Cancer Res. 1986;46(8 Suppl):4244s-4248s.

16. Wolden SL, Zelefsky MJ, Kraus DH, et al. Accelerated concomitant boost radiotherapy and chemotherapy for advanced nasopharyngeal carcinoma. J Clin Oncol. 2001;19(4):1105-1110.

17. Lin JC, Jan JS, Hsu CY, Liang WM, Jiang RS, Wang WY. Phase III study of concurrent chemoradiotherapy versus radiotherapy alone for advanced nasopharyngeal carcinoma: positive effect on overall and progression-free survival. J Clin Oncol. 2003;21(4):631-637.

18. Chen SH, Kuo CC, Li CF, et al. O(6)-methylguanine DNA methyltransferase repairs platinum-DNA adducts following cisplatintreatment and predicts prognoses of nasopharyngeal carcinoma. Int J Cancer. 2015; 137(6):1291-1305.

19. Litvin J, Selim AH, Montgomery MO, et al. Expression and function of periostin-isoforms in bone. J Cell Biochem. 2004;92(5):1044-1061.

20. Takeshita S, Kikuno R, Tezuka K, Amann E. Osteoblast-specific factor 2: cloning of a putative bone adhesion protein with homology with the insect protein fasciclin I. Biochem J. 1993;294(Pt 1):271-278. 
21. Lindsley A, Snider $\mathrm{P}, \mathrm{Z}$ hou $\mathrm{H}$, et al. Identification and characterization of a novel Schwann and outflow tract endocardial cushion lineagerestricted periostin enhancer. Dev Biol. 2007;307(2):340-355.

22. Takayama G, Arima K, Kanaji T, et al. Periostin: a novel component of subepithelial fibrosis of bronchial asthma downstream of IL-4 and IL-13 signals. J Allergy Clin Immunol. 2006;118(1):98-104.

23. Norris RA, Borg TK, Butcher JT, Baudino TA, Banerjee I, Markwald RR Neonatal and adult cardiovascular pathophysiological remodeling and repair: developmental role of periostin. Ann N Y Acad Sci. 2008; 1123:30-40.

24. Yan W, Shao R. Transduction of a mesenchyme-specific gene periostin into $293 \mathrm{~T}$ cells induces cell invasive activity through epithelial-mesenchymal transformation. J Biol Chem. 2006;281(28):19700-19708.

25. Kim CJ, Sakamoto K, Tambe Y, Inoue H. Opposite regulation of epithelial-to-mesenchymal transition and cell invasiveness by periostin between prostate and bladder cancer cells. Int J Oncol. 2011;38(6): 1759-1766.

26. Puglisi F, Puppin C, Pegolo E, et al. Expression of periostin in human breast cancer. J Clin Pathol. 2008;61(4):494-498.

27. Shao R, Bao S, Bai X, et al. Acquired expression of periostin by human breast cancers promotes tumor angiogenesis through up-regulation of vascular endothelial growth factor receptor 2 expression. Mol Cell Biol. 2004;24(9):3992-4003.
28. Takanami I, Abiko T, Koizumi S. Expression of periostin in patients with non-small cell lung cancer: correlation with angiogenesis and lymphangiogenesis. Int J Biol Markers. 2008;23(3):182-186.

29. Kudo Y, Ogawa I, Kitajima S, et al. Periostin promotes invasion and anchorage-independent growth in the metastatic process of head and neck cancer. Cancer Res. 2006;66(14):6928-6935.

30. Kudo Y, Iizuka S, Yoshida M, et al. Periostin directly and indirectly promotes tumor lymphangiogenesis of head and neck cancer. PLoS One. 2012;7(8):e44488.

31. Morra L, Moch H. Periostin expression and epithelial-mesenchymal transition in cancer: a review and an update. Virchows Arch. 2011;459(5): 465-475.

32. Heidari P, Esfahani SA, Turker NS, et al. Imaging of secreted extracellular periostin, an important marker of invasion in the tumor microenvironment in esophageal cancer. $J$ Nucl Med. 2015;56(8):1246-1251.

33. Chan $\mathrm{CH}$, Li CF, Yang WL, et al. The Skp2-SCF E3 ligase regulates Akt ubiquitination, glycolysis, herceptin sensitivity, and tumorigenesis. Cell. 2012;149(5):1098-1111.
OncoTargets and Therapy

\section{Publish your work in this journal}

OncoTargets and Therapy is an international, peer-reviewed, open access journal focusing on the pathological basis of all cancers, potential targets for therapy and treatment protocols employed to improve the management of cancer patients. The journal also focuses on the impact of management programs and new therapeutic agents and protocols on

\section{Dovepress}

patient perspectives such as quality of life, adherence and satisfaction. The manuscript management system is completely online and includes a very quick and fair peer-review system, which is all easy to use. Visit http://www.dovepress.com/testimonials.php to read real quotes from published authors. 